\title{
Functions of alternative punishments to imprisonment in reducing the criminal population of the state prisons
}

\author{
Alireza Milani, Mehdi Rezaee Moghadam* \\ Department of Law, Islamshahr Branch, Islamic Azad Univeasity, Islamshahr, Iran \\ *E-mail address: me.moghadam86@chmail.ir
}

\begin{abstract}
In accordance with the inefficiency of imprisonment punishments in reforming and rehabilitating the prisoners, also due to the criminal environment of the prisons, economic costs of the prison and damages caused by imprisoning the head of the household, contradiction with the principle of personal punishment, health and mental problems existing and the like, are some of the problems which have created serious challenges for the imprisonment punishments. Hence, attempts for employing other punishments as alternatives to the imprisonment punishment have drawn the attention of various countries and legal systems. Accordingly, today the Iranian criminal policy makers, in line with dis-imprisonment and prohibiting the indiscriminate use of imprisonment punishment have begun to enact a law in which a chapter has been assigned to alternatives of the imprisonment punishment and prediction of a half freedom system. This paper, while introducing and investigating alternative punishments of imprisonment in the Islamic Penal Code of 2013 concludes that not only is transparent and clear rules and regulations necessary in this area, but also a successful enforcement of these laws requires an appropriate culture building in the society. On the other hand, the issue of alternatives should be institutionalized among the judges.
\end{abstract}

Keywords: Prison; Imprisonment alternatives; Criminal justice system; Correction; Rehabilitation

\section{INTRODUCTION}

Punishment is idiomatically a retribution which is given to a person who has acted against the laws, customs, morals and habits. From long time ago and in all communities these retributions were imposed in accordance with the statute laws and regulations. With the advancements of societies and appearance of such sciences as psychology, sociology, criminology and law and the like, the type of these punishments have also undergone changes in proportion to crimes and criminal titles. The problems with the imprisonment punishments: constantly imprisoning as one of the most important punishments determined against the offender which is done with the aim of restricting and removing him from the context of the society and divesting his freedom in order to punish them. However, despite a long history of 
imprisonment punishment and its widespread scope in all societies, serious problems are raised against such punishments, resulting in doubts to be cast on its efficiency.

a) Criminal environment of the prison: Prison as a centralized place for thee offenders is always a place for creating felony and crimes. The amateur offenders faced with experienced and professional offenders will learn their new techniques and employ them.

b) Economic and subsistence problems: In parallel with the imprisonment of a person, the lives of other people under his guardianship who lose their financial and economic support will be faced with disintegration, where this could cause a secondary motive for crimes.

c) Social problems: Imprisoning people will incur social problems. Of which we can refer to the very foundation of personal life being affected, changes to his perspective of the society, and distortion of his social prestige.

d) Government incurred losses: States must always pay costs for the management of the prisons.

On the other hand, Reforms and changes made in the Islamic Penal code of 2013, especially in articles 64-87 of chapter 9 about the alternatives punishments to imprisonment have prepared a ground for the complete fulfillment of such alternatives where this will involve an effort by al judicial and stat outfits.

\section{First subject: Objectives and characteristic of imprisonment alternatives}

Here, in this part which consists of three subjects, the concept of alternative imprisonment is first examined in the view of the lawmaker and then judicial alternatives, i.e. in the court and in the sentencing stage in accordance with type and severity and perils of the crime where the specification of the punishment is entrusted with the judge will be investigated and finally, objectives and benefits of imprisonment alternatives will be examined.

\section{First word: Concept of imprisonment alternatives}

For the first time, Enrico Ferry, the founder of the positivism school employed the term "criminal alternative". For him, these alternatives must become the main tools of social defense, because they are regarded as great antidotes for the social factors of felony. In other words, it is those preventive measures and social defense which are considered at the social level as a whole and in the area of judicial structure. After Ferry, Gramatica, the founder of the social defense school offered a new interpretation of the concept of alternatives policy and he stated sociopathic should be at first replaced with responsibility and second, the sociopathic signs and its degrees should be regarded instead of felony; third, the social defense tactics in line with the needs of any offender should replace the appropriate punishment of the felony (Pradell, 2002).

Alternative punishments are intermediate punishments; i.e. between prison and socalled under arrest pursuit or alternative or social sanctions used instead of dispatching the defendants or convicts to the prison. Those advocating imprisonment have enumerated three privileges for this: 1) if we remove prison in countries where execution is performed, judges will be highly inclined to execution, therefore prison is a necessary factor, 2) prison will disempower the offender and divest him from doing the offense, and 3) most but not least if we eliminate prison, how dangerous felons should be treated?. Some others maintain prison 
should be removed. We can however examine the concept of imprisonment alternatives in two areas; legislative or legal and judicial concepts.

\section{- Legislative alternatives}

In this area, the lawmaker by considering the criminal policy of a country foresees such criteria as severity and importance of a crime committed and the personal and personality characteristics of the offender before and after the commission of the crime. For example, instead of the imprisonment punishment, a fine penalty under article 3 of the law on the receipt of state revenues in clear instances enacted in 1996 and suspension of punishment execution under article 25 of the Islamic penal code and the like are manifestations of the legislative alternative policy. Most of the instances brought in relation with the imprisonment alternative in the 2013 Islamic penal code are legislative alternatives foreseen in order to eliminate the detrimental effects of the imprisonment punishment. Although the selection and enactment of judicial alternative methods are in fact provided to the legislator, the difference being that the judge in the legislative alternative is obliged to replace the imprisonment punishment with retribution.

- However, in the judicial alternative, the lawmaker while maintaining the imprisonment retribution allows the judge to proceed to replace the imprisonment with retribution in case conditions and the principle of personal punishments are established.

- Like the suspension of executing the punishments under article 25, Iranian Civil law

\section{Judicial alternatives}

This concept is the same mentioned by Jean Pintail under the name of "Prison short term retribution alterations", which is to say the courts (judges) in the stage of determining the punishment by considering the type and level of severity and perils of the crime committed and the social circumstance of the crime commission and the background and perils of the crime have the authority to foresee alternatives instead of issuing the imprisonment verdict. In the 2013 Islamic penal code, judicial alternatives are also foreseen. Articles 66 and 67 provide respectively:" the court can sentence the offenders of intentional crimes whose maximum legal punishment is up to 6 months to one year in imprisonment to punishment alternatives to imprisonment" and " the perpetrators of the unintentional crimes are sentenced to the punishment alternatives to imprisonment unless the legal punishment of the crime committed is more than 2 years imprisonment, where in this case, a verdict to the imprisonment alternative punishments is optional".

The court's option in determining alternative punishments is indicative of prediction of legislative alternative punishment in the new law.

\section{Second word: Objectives and characteristic of imprisonment alternatives}

Imprisonment alternatives enjoy some objectives and privileges where they are investigated in two words:

- Objectives of imprisonment alternatives

1. Better enforcement of justice: Considering imprisonment alternatives does not mean removing the prisons and other punishment, rather it is an attempt for completing them and diversifying criminal options the judges possess. In this case, judges for the crimes have appropriate options at their disposal. 
2. Reduction of economic costs: One of the biggest thinking concerns of the officials is to reduce the budget and raising the costs, because costs will skyrocket with the increase of prison population.

3. Increase of control over prisoners: Accumulation of prisoners will render in decreased control over them. Of the most important reasons for the prevalence of addiction even inside the prisons is libertinism and the like, where the alternatives to imprisonment are of the most important factors for reducing the number of prisoners.

4. The social situation of the felon not being lost: Using the alternative punishments will result in the person not to be removed from the family environment and the friends and not to distance from his occupation and situation.

Hence, the imprisonment punishments seem to be applied for the offenders whose freedom is dangerous and could endanger the security and convenience of the society.

\section{Characteristic of imprisonment characteristics}

Participatory and social: "Social punishments are retributions that restrict personal freedom and rights and involve corrective properties which are executed inside the community for a group of offenders by the supervision and the care of the community and of civil institutions". In an extended criminal policy sense, only the state as meaning various official entities like the courts of justice, ministries and the like are not held to provide answers to a criminal phenomenon, rather the answers provided by the civil society and various popular institutions are also added to state answers. Engaging the public in the criminal policy, in addition to removing the legitimate trepidation for raising its effectiveness means today preventing and oppressing felony are of affairs related with all the people (Lazerge, 2011).

Thus, today the role of people in the process of the criminal justice is increasingly becoming prominent and along official institutions and organizations, people contribute highly to maintain the interests of the society. One of the characteristics of the punishments alternative to imprisonment is it being social and the convicted endures his punishments in the community. In the bill on social punishments alternative to imprisonment in article 1 , the participation of people and civil institutions are explicitly cited while executing social punishments, but in the new Islamic penal code this phrase is omitted. However, in accordance with the inherent participation of people in these types of punishments, this omission has no effect in reducing the peoples' role in executing these punishments.

Bilateral agreement: Of the most important properties of the punishments alternative to imprisonment is the bilateral agreement; i.e. in addition to the will of the judicial authority, the will of the felon is also necessary so that these alternatives are found to be applicable. This approach places the will of the felon in line with that of the judicial authority and brings it out of a vertical and unilateral state, rendering in an active role for the felon in the hearing process. (Niazpoor, 2011). Accordingly, felons are thought as one of the parties to the criminal agreement and they are entitled to proceed to investigate the dimensions of the recommendations by the judicial authorities. Moreover, they can reject or approve the recommendations by the authorities. Hence, felons as acceptors of the recommendation by the judicial authority like the prosecuting attorney could intervene in the bilateral agreement process (Niazpoor, 2011), Because, ruling on alternatives to imprisonment involves some physical and mental restrictions for the accused, the offender should be satisfied with its execution; which is to say the offenders have the right to be fully aware of the work they are demanded to do (Ashoori, 2002). 
Agreement and consent regarding the alternatives to imprisonment have been explicitly accepted in the Islamic Penal Code, including in article 83 which states: " Free public services are the services issued in the verdict as with the satisfaction of the convict". Also, concerning the electronic supervision in article 61, the satisfaction of the convict is regarded as the condition for the enforcement of the punishments. Concerning other alternatives (under arrest period, daily fine penalty, fine penalty), though not explicitly mentioned in the law, as long as the offender has no will to commit it, the execution of it will not be possible and the same imprisonment punishment will be carried. In line with provision 3 of article 83 "the convict's dissatisfaction to do public services renders in the carrying out of the main punishment according to the ruling".

\section{Revocation}

One of the characteristics of alternatives to imprisonment is revocability and that happens when the offender does not live up to his obligations where in this case, the same preliminary punishments which are imprisonment will once again be enforced. In fact, the sanctions for the non-enforcement of the alternatives to imprisonment properly, are the application of the same imprisonment stipulated in the ruling. Under article 69 Iranian Civil Code: "the court while determining alternative punishments will also specify the time period of punishment in case of non-enforcement of alternative punishments, or violation of the orders and inability to pay the fine penalty, punishments of imprisonment will be carried out". Also, corresponding to article 80: "if the convict violates the execution of the verdict provisions or the court's orders, as recommended by the judge executing the verdict and court's decisions, at first one-fourth to on-half is added to the punishment and in case, repetition occurs the imprisonment punishment will be enforced".

\section{Suspension, conversion and commutation}

If due to an external impediment outside of the will of the convict or due to some excuse relating to the convict, it is not possible to temporarily enforce it, it can be suspended. Under article 81 of the Iranian Civil Code: "if the execution of all or part of the alternative punishments face with a hurdle, the punishment under the verdict or the non-enforced part of it will be executed after the elimination of the impediment. If the mentioned impediment is created by means of an international behavior of the accused and done for stopping the punishments, the main punishment will be enforced".

Also, as per provision 4 of article 83 of this law: "the justicer (the judge issuing the verdict) could in accordance with the physical state and the need for medical services or some familial excuse and the like suspend the public services either temporarily or to a maximum 3 months during the time period, or it can recommended its conversion to some alternative punishments to the court issuing the verdict".

As seen, this article only involves one of the alternatives to imprisonment, i.e. doing public services, cases for suspension and conversion of it and it is not clear whether other alternatives to imprisonment can be converted or suspended. Article 79 of the Iranian Civil Code has stated a commutation of punishment after the verdict becomes executable. In line with this article, "if the observance of the provisions of the court's ruling by the convict suggests his conducts being corrected, the court could at the recommendation of the justicer halves the remaining punishment once. 


\section{Non-repudiation of the offender by the community}

Alternative punishments to imprisonment are employed such that they do not hinder the normal life of the convict and the person while living in the community like others will bear the punishments. The convict will not feel he is ostracized from the society and does not consider him a victim of it, rather he still has the feeling towards his fellow men and as time lapses he will return to the community. Under article 83, Iranian Civil Code:" Hours of providing public services for the working and non-working people is not more than four and eight hours respectively. However, the hours for providing services in daylight should not inhibit the conventional subsistence of the convict". As the article states explicitly, the alternative punishments to imprisonment should not be enforced such that it will impede the normal life of the convict and makes the situation tougher for him, thus resulting in mental and economic pressure for him and his family.

\section{Second subject: Conditions and types of imprisonment alternatives in the 2013 Islamic Penal Code}

Our legislator, despite a series of alternative punishments in the Islamic Penal Code and enforcing them in the society concludes that the presence of the alternative punishments have been helpful and effective and could reduce damaging effects, and hence bring about benefits for the state. Thus, the Islamic Penal Code 2013 in chapter 9, by stating the alternative punishments "alternative punishments to imprisonment include under arrest period, free public services, daily fine penalty and deprivation from the social rights (Article, 63 of the Islamic Penal Code 2013)" addresses conditions for granting it.

\section{First word: Conditions for granting the alternative punishments in the new law}

Article 64 states "alternative punishments to imprisonment include under arrest period, free public services, daily fine penalty and deprivation from the social rights, whereas in case of the plaintiff's forgiveness and presence of abatement grounds by considering the type of crime and quality of its commission, implications caused by crime, age, skill, personality status, crime record, the situation of the victim and other circumstances are determined and enforced".

\section{First clause: Complainant's forgiveness}

The complainant could be investigated in two senses, by the complainant in the general sense, it is the public prosecutor and in the special sense, it is the private complainant. Hence, the legislator has laid a series of conditions for the alternative punishments where one of the main conditions is to acquire the satisfaction of the private complainant. Of course, forgiveness has its own conditions: 1) Forgiveness must be without constraints and shackles, 2) deviation from the forgiveness is not justifiable, and 3) if the number of complainants varies, forgiveness by some of them is sufficient and forgiveness by all of them is not necessary (Ardabili, 2003).

\section{Second clause: Abatement grounds}

Under article 37 of the new law "abatement grounds are 1) forgiveness by the complainant or the private complainant, 2) defendant's effective collaboration in identifying the partners and accomplices, 3) special circumstance affecting the crime commission, 4) announcement by the defendant prior to the prosecution or his effective confession, 5) 
repentance and the good record and the special state of the defendant, including aging and illness, 6) attempts by the defendant to abate the crime implications, 7) mitigated damage inflicted on the victim or the mitigated crime incurred losses and 8) weak intervention by the accomplice or the partner in the crime happening".

Now the question is why does the legislator bring the forgiveness separately and he does not adopt the abatement (mitigation) grounds despite the fact the complainant's forgiveness is one of the abatement grounds?. It seems whenever one of the eight fold mentioned instances is fulfilled it suffices, but the legislator, respecting the complainants' forgiveness which is one of the grounds for abatement has attached so much importance that it should exist along with one of the abatement grounds so as to enjoy alternative punishments.

\section{Third clause: The way alternative punishments are enforced}

With respect to alternative punishments the question that comes to mind is whether its enforcement is compulsory on the part of the legislator and defendant in cases where they are determined by the legislator cannot accept the main punishment. Now, in the following clause the compulsory and optional alternatives and even the prohibitions for applying the alternative punishments are investigated.

\section{Compulsory alternative punishments}

a) In intentional crimes:

1. If the maximum legal punishment for the crime committed is three months (article 65 of the2013 law of punishment)

2. If the maximum legal punishment for the crime committed is between 91 days to 6 month imprisonment and the convict has had no conviction record and if he has, the conviction must have exceeded five years.

b) In unintentional crimes:

The perpetrators of the unintentional crimes whose legal punishment is less than 2 years in jail.

Optional alternative punishments

The enforcement of the alternative punishment to imprisonment in intentional and unintentional crimes is optional by the courts in the following cases:

a) In intentional crimes:

The court can convert the perpetrators of the intentional crimes whose maximum legal punishment is 6 months to 1 year in jail to alternative punishments.

b) In unintentional crimes:

The perpetrators of unintentional crimes whose legal punishment is over two years in jail (article 68 of the new law).

\section{Prohibition of the enforcement of the alterative punishments}

Since the philosophy of the alternative punishments was discussed in the previous chapter, we conclude that the application of alternative punishments is in some cases useful instead of imprisonment punishment and in cases too, in accordance with the severity of the crime and avoiding the criminal being embolden, the application of the main punishment is necessary. Now, the legislator by considering benefits in the following cases has prohibited the enforcement of the alternative punishment, even its degree is low: 
1. In cases where the crime is against the domestic or foreign security (Article 71 of the 2013 punishment law)

2. In a number of crimes where the legal punishment for at least one of them is over 6 months (Article 72 of the 2013 punishment law)

3. In intentional crimes whose legal punishment is more than a year in jail.

\section{Second word: Types of alternatives to imprisonment in the 2013 Islamic Penal Code}

1. Under arrest, 2) Free public services, 3) Fine penalty, 4) daily fine penalty, 5) deprivation from the social rights.

In the following, the focus is to investigate the concept briefly and the alternative punishments themselves.

- Under arrest

Here, attempts are made to deal with the following cases: concept of under arrest, objectives and its state in the Iranian criminal law.

\section{Concept of the under arrest}

According to the legislator's definition (article 83 of the 2013 Islamic penal code), the under arrest period is a period during which the convict on the ruling of the court and under the supervision of the justicer is sentenced to do one or several instances of the orders set forth in under arrest postponement.

\section{Under arrest objectives}

1. Embracing the criminal and avoiding the renewed commission of the crime through providing facilities for correction and treatment.

2. Reduction of the prisons population, not only will the criminal survive the mental and psychic pressure sin the prisons but also this will reduce the possibility of the crime from being repeated.

- $\quad$ Free public services

The second punishments alternative to imprisonment by the legislator in the 2013 Islamic penal code is free public services and services of public utility (Hajitabar, 2007). Doing the public services by the convict is not synonymous with joblessness and hard labor, rather it is in line with rehabilitating and correcting the convict through avoiding negative effects of conviction to the prison, utilizing the rehabilitation capacities, working in public utility sector and also compensating the damages done by the criminals inflicted on the society.

\section{Concept and definition of the free public services}

Free public services mean doing some work which is in interest of the state freely. The term services means doing some work, giving gifts, working and missions. These services are issued by the court's mandate and because of that the felon is given the chance to compensate for the damage he has inflicted on the society, without his imprisonment retribution is once again applied. 


\section{Free public services objectives}

1. Avoiding the unfavorable mental and social effects of the prison on the prisoner and correcting, treating and social adjustment of the convict through engagement in work of public utility

2. Compensating the damages the criminal has inflicted on the community by his commission

\section{Conditions and the way the free public services is granted}

The implementation of the free public services includes not all the imprisoned groups. Dangerous felons are deprived of this privilege. Such a ruling only includes the felons who have committed unintentional felonies and do not darn dangerous for the community. In this regard, the courts have to perform exact researches in regard to the background of the felon and his personal situation so that they make sure the felon possesses the ability to utilize and impellent fully the ruling.

\section{- Daily fine penalty}

The third alternative punishment to imprisonment introduced by the legislator in the 2013 Islamic Penal Code is the daily fine penalty. With all the advantages the fine penalty, a problem has always haunted the criminologists and researchers and that is the inability of the convict to pay his fine due which leads to imprisonment punishment instead of the fine penalty. Hence, the legislator by foreseeing the daily fine penalty has sought to solve this problem.

\section{Concept of fine penalty}

Concerning the fine penalty on daily basis, no special definition is yet offered by the legislator. For some of the lawmakers, we can define it as:" Daily payment of a sum of money to the state as punishment which is related with the severity of the crime committed and the level of the convict's daily income".

\section{Objectives of the Daily fine penalty}

1. It is an alternative for the imprisonment punishment due to problems with the imprisonment retribution

2. It is an alternative for the fine penalty punishment so that it modifies some of the problems arising from the fine penalty

3. Of the most important goals of it is to create justice and equity in the way this sort of sanction is implemented because the fine penalty degree is specified in proportion to the personal daily income.

\section{The way daily fine penalty is implemented}

According to article 85 of the 2013 Islamic penal code "the fine penalty on daily basis is one-eighths to one-fourth of the daily income of the convict received by the supervision of the ruling implementation.

- Deprivation from the social rights 
The legislator in article 64 of the 2013 Islamic penal Code has considered deprivation from the social rights as one of the alternative punishments. But ion chapter 9 which is assigned to alternative punishments, there is no article for this matter.

\section{Concept of social rights}

Social rights is rights the legislator has stipulated for its own nationals in relations with public institutions; like political rights- right to employment- right to choose-being elected in legislative sessions and conferences and state and provincial and municipal associations testimony ion official authorities and being authentic (Langaroodi, 2008).

Moving toward an integrated strategy

By this strategy we mean how we can design alternative to imprisonment so that people are wholly kept away from reference to the criminal justice system and meantime, how we can make changes to any level of the system so that imprisonment punishment is used little. Any strategy related with reducing the prison population requires the following:

- Scientific basis

Judicial authorities need sufficient information about the general series of the criminal justice system activities, including imprisonment and its alternatives and also an analysis of the prisons population.

- Political innovations

Politicians should apply this information for introducing and providing a clear policy about the alternative imprisonment which reduces the prison population. In fact, the senior politicians and policy makers share an ideological commitment in order to reduce the prison population and imprisonment alternatives. Judicial authorities should in attaining a general support for this policy notify the pubic the imprisonment shortcomings and costs and the moral, practical and financial benefits of its alternatives.

- Legal reforms

Judicial authorities, in order for a strategy concerning the alternatives should inspect the law and make sure the law except for necessary occasions does not consider a behavior as crime and does not increase the prison population. The law should maintain the alternative to imprisonment as necessary and takes it as the last resort.

- Expansion of alternatives

Judicial authorities assume the responsibility to introduce the overall benefits of the alternative strategies to imprisonment in the public presence. The aim of most of the strategies is to reduce imprisonment.

The government can expand the preliminary awareness and understanding and as a result, the public will be made aware of the imprisonment costs and the benefit of its alternatives. In initializing and expanding the alternatives, the state should participate with the organizations that work in the criminal judgment section professionally and the NGOs who are active in the area off crime and punishments.

The state by illustrating the benefits of the imprisonment alternatives in the benefit of the victims should acquire the support of the victim groups. The government should acquire the public vote in regard to the benefit of the alternatives. Surveys indicate that whenever people are asked about the criminals' punishment, they generally call for punishments, but when they are given the exact information this call lessens. 


\section{CONCLUSIONS}

Because imprisonment involves dangerous effects, the consensus offered by the rules and standards of the United Nations is that the member states apply the alternative imprisonment in order to reduce the prison population. The United Nations' rules and standards accept the application of imprisonment as the last resort and in the shortest time possible. In comparison to imprisonment, alternative imprisonments are often more effective in attaining the main objective of the public security like more security for people. If they are properly designed and implemented, while incurring little costs will violate human rights in the short and long term to a lesser extent. The first strategy is to keep the criminal away from the criminal justice system. The entire unfavorable social conducts should not be classified as crime or be treated through the criminal judgment. Removing crimes will not define a conduct when it is legally considered crime.

Another strategy, is reframing from judiciary where the options in dealing with criminals instead of referring them to the courts for punishment will introduce them corrective and rehabilitator programs. Imprisonment at the stage before the trial, particularly the detention of people suspicious of innocence is an aggravated violation of the personal freedom. Only under totally restricted circumstances this sort of detention is affirmed. Freedom before due time has drawn attention with respect to some special groups of the offenders who are vulnerable against the negative effects of imprisonment like children, women, and mental patients and people who have committed crimes relating to drugs.

\section{Recommendations}

1. Using the alternative punishment to imprisonment should be gradable and based on observing the rules

2. Respecting the principle of proportion requires a formation of character dossier along with the judicial case, not that this duty is assigned to the board of government during regulations

3. Supervisory and care guidelines and institutions and entities responsible for implementing them should be foreseen

4. Using the previous experience and research in other countries with respect to the alternative punishments by considering the social and cultural realities of our country that could be effective.

\section{References}

[1] Ashoori M. (2002). Alternatives to imprisonment and in between punishments, Tehran: First vol. Gerayesh publication.

[2] Ardabili M. A. (2003). General criminal law, Tehran: Second vol. seventh edition, Mizan.

[3] Hajitabar Firoozjaee H. (2007). Alternatives to imprisonment in the Iranian criminal law, Tehran: First edition, Ferdosi publication.

[4] Pradell J. (2002). History of criminal thoughts, Trans by Ali Hussein Najafi Abrandabdi, Tehran": First edition.

[5] Niazpoor A. H. (2011). From criminal law to arbitrary criminal law", Criminal aw teachings, Faculty of Razavi Islamic Sciences, No. 1, Summer and spring. 
[6] Niazpoor A. H. (2001). Agreement over the criminal procedure code, Mizan publication, First edition. 